\title{
SOURCING DATA IN POPULAR MUSIC RESEARCH IN NIGERIA
}

\author{
Arugha Aboyowa Ogisi* \\ http://dx.doi.org/10.4314/og.v12i 1.9
}

\begin{abstract}
The dependence of popular music on the media for its dissemination throws up a new set of challenges for scholars operating with traditional music and art music. However being music he/she still has to investigate the time tested sources along with new sources that are now usually used or looked up to for data. However, such sources or the new approach uses established source that popular music research has spun. This paper therefore highlights these sources and shares the personal experience in using both the conventional and unconventional sources in the hope that it will ultimately reduce wastage of resources and increase the quality of scholarship in popular music.
\end{abstract}

Keywords: Data, Popular music, Music Research, Nigerian Music, Music Scholarship

\section{Introduction}

Unlike well established areas of music studies, popular music has several research challenges one of which being that most music scholars are unaware of some of the various sources of collecting primary data and what such sources portend for research. This is not unusual of a fledgling discipline. The writer was confronted with this challenge preparatory to the fieldwork of his doctoral thesis and had to literally prod his way blindly through. Precious time would have been saved had there been information to guide the effort. This paper is an effort to provide assistance for those with similar experiences, thereby saving them time and effort.

The subject of data source has not attracted the attention of most Nigerian music scholars despite its importance in research undertakings. Apart from Nzewi (1980) who was essentially warning the researcher of the potential pitfall inherent in the use of incompetent translator, no other publications have addressed challenges encountered by music scholars engaging in fieldwork in 
Nigeria. While some field experience are universal, there are also peculiarities of each field environment that needs to be highlighted so that researchers planning to conduct fieldwork in the area will adequately prepare, materially and mentally to confront the challenges head. Thus the entire area of research methodology is yet to benefit from the insights and field experience of others as there are nosign posts that point the way to the wayfarer. The object of this paper therefore, is to discuss the various sources where primary or secondary data exist in Nigeria in respect of popular music.

This study is basically descriptive and data utilized were obtained from interviews, observations and experiences during a three-month fieldwork where visits were made to some broadcast organisations, the national archives at Ibadan and Enugu and libraries of Universities with Departments of music in south-western Nigeria and interviews were conducted with music broadcasters, musicians and producers. The following section discusses the offering of the sources from where data were obtained for the study.

\section{Sources of Data}

Data for popular music studies present in literary and audio/audiovisual formats any of which could be primary or secondary. Data is primary when it is evinced by an eye witness and referred to as secondary when it is the narrative of one who was not a witness. Studies in Nigerian popular music should as much as possible use primary data dependent because of its inherent possibility to unveil new facts. They will thus further the frontiers of knowledge especially in such an area of study where not much research has been done and it remains largely uncharted territory. Apart from the use of primary data, secondary data are useful for their potential in offering new insights that may not exist in primary data. It is best to combine both types of data because they corroborate each another thereby leading to meaningful and reliable interpretation. The decision to make this study primary data driven also derives from the fact that secondary data in the form of literature is scarce so there is no option than to depend on primary data. Primary data exists in the reminiscences of practitioners, their acquaintances and patrons and in memorabilia. Secondary data exists in the popular press as performance reports, advertorials and photographs in newspapers 
and magazines; records; hand bills; posters; field recording and programmes of radio and television stations; government papers and publications, books, thesis, journals, government publications and papers, commercial recordings, and radio and television programmes while primary datawere obtained from interviews, observations, and focused group discussions.

These sources can be classified under three broad groups: Literary sources, Audio-visual sources and Internet Communication Technology (ICT) sources.

\section{Literary Sources}

Literary sources are written materials which may be published or unpublished. By being published we mean that they are in wide circulation without hindrance as to access paying for them, and are written in paper or hardcopy. The published literary books sources are books, journals, newspapers, magazines, blogs, and internet while the unpublished literary sources are theses.

\section{Published Literary Sources}

Published literary sources are books, journals, newspapers, magazines and theses, government reports, books represent an important source of data for historical studies as they documentextant knowledge in the area. However the fact that there are no books yet on several aspects of popular music in Nigeria, weakens its potential of a data base. This notwithstanding, there are a few books. There is a book Juju music (Waterman 1991), two biographies (Uwaifo 1975, Obey 1992) and one on performance context (Omojola 20??). Apart from these books there are other general books that offer valuable data.

\section{Journals}

The Journal is an important source of data as it is concerned with studies that represent the frontiers of knowledge within a discipline although, few scholars have published articles on aspects of Nigerian popular music such as its history, genres, themes, performance context etc. This situation notwithstanding, it remains a valuable source of data especially on the origins of genres and the major factors that influenced the development of popular music in Nigeria, 
(Refer to Appendix I). It is worth noting that despite the relative short period of its existence as an academic discipline, popular music now has vibrant dedicated journals in various parts of the world (Refer to Appendix II).

\section{Government Publications}

Government publications represent a source of dependable data, some of which cannot be generated by a researcher or are generally unavailable elsewhere. During the colonial period, government published the Blue Book (from 1962 to1945) and later the weekly gazette containing reports from government departments. Some of these publications contain valuable data pertaining to the development of popular music in Nigeria.

\section{Newspapers and Magazines}

Since the beginning of newspaper publication in Nigeria with IweIrohin in 18, the press has regarded music as its legitimate territory. As literacy and political consciousness spread and the country was being opened up by inland water ways, rail, roads and airport infrastructure, so grew the number of newspapers. As the economic and latter political capital of Nigeria, Lagos has remained the choice place to establish newspapers in Nigeria. From 1882 when newspaper was first established in Lagos, other newspapers followed through the years with some becoming moribund and others were beginning. Following the spread of literacy, newspapers were established inland having the privilege to come after Lagos. Subsequently newspapers came to be established in other parts of the country.

In employing the newspaper source, the researcher must realise the fact that from the onset, newspapers were enterprises driven by the profit motive. The objectives in establishing them informed their offerings and coverage. In this regard, newspapers, and magazines in Nigeria classify as local, regional and national. Local newspapers have limited coverage to a city or beyond. Regional newspapers circulate within groups of States while national newspapers are national in outlook and coverage.

Conscious of the fact that newspapers document happenings in the society on daily basis, it is therefore expected of one 
researching the history of a local music genre to consult the local newspapers that existed in the area when the music was in vogue. His/her efforts are likely to be rewarded with at least a photograph of a musician in performance, or reports or adverts of a performance.

In searching for newspapers to use in one's research there are no one-stop shop to find them. The closest there is the collections of the National archive but even this have gaps. Libraries should be an alternative but their collections are usually not comprehensive. Although most libraries purchase just a few newspapers, the surest source of these old newspapers are the establishments themselves which means that the researcher has to do a lot of travelling in order to achieve his purpose. However this caveat is not as promising as it seemsbecause most newspapers and magazines in Nigeria do not survive beyond three years of operation. This brings us to the issue of this high rate of failure should have stirred up funding of the National Library to undertake its task of preserving this aspect of our national heritage. While this remains, the researcher must seek ingenious ways of obtaining data from such a source.

It should be mentioned that the National Library is the legal repository of all publications in Nigeria including newspapers. Despite this most publishers do not bother to send their publication to it. On the other hand, the National Library lacks the wherewithal to undertake the gigantic task that it is charged with.

Although music is a concern of newspapers, the early newspapers concentrated on art music although they carried adverts of social events involving the use of music of a popular disposition. However, it was not until the 1920s that newspapers began to address popular music in the forms of reports, features, interviews, reviews, photographs, articles, comments, critics etc. As regards Nigerian music, the West African Pilot was the first newspaper to give special attention to African musical subjects and popular music in particular. In the 1950s, it engaged Agu Norris, a reputable popular musician of the era as a columnist on Nigerian popular music. The West African Pilot is a veritable source of data on the popular music of the period; it was being published before it went defunct. The benefits of this source of data notwithstanding, the researcher must be mindful of the tendency of the media towards 
sensationalism and exaggeration.This weakness notwithstanding newspaper still hold promise as a reliable and important source of data in popular music research since they document musical activities on a more surreal basis.(See appendix II)

\section{Unpublished Literary Sources}

These are book materials that are not readily available and usually not for sale but access to them are restricted. They are projects, dissertations, thesis, and monographs. They are often done in fulfilment of the requirements towards a certificate from an institution of higher learning.

\section{Projects, Dissertations and Theses}

Thesis, Dissertations, Projects and other similar research results indicate the frontiers of knowledge in a discipline. Apart from journal, they are very reliable data source for research. Unfortunately few theses (Aladja-brown 1985, Okereke 1988, Emielu 2009, Idolor 2001, Loko 2009, Ogisi 2009, Oikelome 2009, Olusoji 2009, etc) have been executed on Nigerian popular music. However, the researcher in music utilizes what they offer.

\section{Reports/White Papers}

Apart from publications there are government files that have been declassified and available to researchers in the National Archives. For example there are files on the Constabulary Band, Bobby Benson, some of the early bands or music groups. It was a delight to find data of historical significance to Nigerian popular music in some of these files. However, most of the files in the Archive at Ibadan are about the Lagos colony because of the long period of British presence in the area, while the files at Enugu and Kaduna Archive host records of government activities in the former Eastern and Northern regions respectively. Apart from the National Archives some institutions have bequests of special holdings in their charge. For example the University of Ibadan has the Herbert Macaulay papers and the University of Nigeria has similar materials in their special collections. Institutional libraries are places to direct one's search for materials pertaining to individuals or organisations. 
In the course of governance, there will be situations that decisions cannot be made because the cabinet does not have the fact to do so. In such situations the practice is to set up a technical body to examine the issues and make recommendation(s) to government. Such recommendations come in the form of special report that are not published and so not readily available to the general public. Such reports contain valuable facts that may be beneficial to researchers. Government examines the recommendations and decides on the recommendations. The decisions come as white paper which again is not widely available to the public. There are several government reports/white papers and they come in various names such panels, commissions. These are valuable sources of research data on several aspects of Nigeria's National life.

\section{Audio and Audio-Visual Sources}

These recordings of sound or pictures are presented as records, cassettes, cartridges, compact disk, VCD, reel-to-real tapes. They may be analogue or digital and requires specialised equipment to play. In recent times some equipment have been developed to convert a format to another.

\section{Records}

Recording, as used in this context, are audio-visual products in whatever format they appear. Records are both sources as well as forms of data. They exist in commercial and non-commercial presentations but the later predominates. They are reliable as evidence of the state of genres at the time of recording thus they are very useful for historical studies. However, it must be noted that commercial recording does not represent all the available genres in a society at a particular time because the record companies, as enterprises, choose to record only what they consider profitable. It is therefore not unlikely that in a society with up to seven genres, only four of them may have been documented in recordings. This is more so as there are no state organs or private bodies that are charged with capturing for posterity the transient aspects of our culture.

However, Broadcast organisations in Nigeria especially those that existed prior to independence have a robust collection of records of Nigerian popular music in their record libraries. Of 
particular note in this regard is the records library of Radio Nigeria, Lagos, which started collecting records in when Lagos Radio was established. The holding was inherited by the Nigerian Broadcasting Service (NBS) which metamophosized to the Nigerian Broadcasting Corporation (NBC) and thereafter to the present Federal Radio Corporation of Nigeria (FRCN). Apart from Lagos the regional stations at Ibadan, Enugu and Kaduna have sizeable collections of records. During the early 1950s, the colonial government set up provincial radio stations in the headquarters of twelve provinces. There were radio stations in Warri. Some of these stations, like that in Warri, have continued broadcasting from 1952 when it was established, to the present. Under normal circumstance the station should have a reasonable holding of records of popular music that were prevalent in the area through the years. As producers of record products, records companies are reliable sources of data for the researcher. The content, the album sleeve, artiste files, account books, written correspondence with the musicians etc are of immense assistance to the researcher especially in historical research.

The end users of recording products are individuals who as music enthusiasts are in the habit of purchasing records of their favourite genres and those in vogue. With continuous purchase they amass a large collection of records, through several years. There are also hotels or former hoteliers, cinemas, cinema owners, night club or night club operators who by the nature of their business have a large collection of records. Contacting such persons can offer the researcher enormous data especially from the piles of record album sleeves they hold.

Nowadays, with improvement in technology from analogue to digital format leading to abandonment of vinyl for the compact disc and nay the DVD recordings products are no longer enduring as they used to be.By the rate things are at present it is likely that in a few years time there will be no trace of the music of this era because the recording format currently in use is not enduring. Although the CD, DVD represents major strides in recording technology, the challenge of not being long lasting remains a major setback in music scholarship. Until this is done, we stand the change of losing a major aspect of the documentation of contemporary culture. 
Outside the country some broadcasters such as the Voice of America, (VOA) and the British Broadcasting Corporation (BBC) have done excellently well in housing reasonable collection of records of Nigerian popular musicians that were not documented by recording companies. So in reconstruction studies commercial records should be used in conjunction with data obtained from other sources.

\section{Radio/TV Music Programmes}

Another source of audio-visual data are programmes of radio and television broadcasters especially those that were made before 1980 . Some of them are interviews conducted with musicians, recordings of live performances etc. The first generation radio and television stations ${ }^{1}$ have such vintage recordings that go back to the 1950 s. Radio Nigeria, Ibadan has audio recordings of studio and stage performances of several juju musicians of the 1950s. In the course of a fieldwork in 1991, I listened to a tape recording of Ojoge Daniel in the studio of Radio Nigeria, Ibadan and the recording demonstrated that during the 1950s, juju was stylistically similar to highlife. It was therefore evident that each of them developed on different paths over the years that by the 1960 s they were clearly distinct. I was able to listen to this because of extent practice of preserving broadcasted programmes. It is worth mentioning that from the beginning of broadcasting in Nigeria to the early 1990s, Nigerian broadcasters regarded the production of programmes as the core aspect of their job. As a result there were various types of programmes including live studio performance of bands or musicians. Most broadcasters preserved such programmes which are reliable sources of music data for the researcher. However, when the Nigerian economy was in a dire state in the early 1980s, governments across the country took steps to curtail government's expenditure profile across board. The measure adversely affected broadcasting because by its nature, unlike other sectors of public expenditure where the major cost is capital, recurrent expenditure broadcasting is very high with most of it going into programme production. So when government decided to pay emolument and directed the stations to commercialize their services, it gradually cut down the programming budget that by year 2000 nothing was being provided for programme production. The 
real effect is that it stopped government owned broadcaster from being documenters of the nation's cultural and musical heritage. This led to lack of basic resource such as tapes and in a bid to keep up with a similitude of their essential services, producers scavenged for tapes of old programmes including the vintage studio performances, wiped off their content for reuse. This went on in virtually all the government owned stations across Nigeria. I personally witnessed this during my field work at the height of this insanity in $1990-1992$. What a loss.

In more thoughtful organisation such destruction cannot be. For example, in the $\mathrm{BBC}$ or VOA it is legally and practically mandatory to preserve such recordings. The issue is not only financial but equally attitudinal. As a people, we pay lip-service to what makes us unique.Since the inception of commercial broadcasting, government owned radio and television stations have ceased playing the role of documenting music for posterity as was the case prior to the 1990s. With the mantra of privatization, broadcasting in Nigeria has sunk to its lowest ebb that broadcaster no longer engage artistes ${ }^{2}$ to produce programmes, unable to pay for the services of musicians or even shoulder their basic transportation cost. This should not have been and must not be allowed to continue.We need to sound a word of caution for those who may wish to take advantage of this source in collecting data as such hopes may, in most cases, be dashed because there may not be such archived programmes in many stations. With this trend, the researcher has no place to turn to in respect of capturing what the music under study sounded and no interviews to draw data form.

\section{Film}

Film holds potential as source of data for music research as it was only sparsely being used in documenting Nigerians music officially. During the colonial era and into the first republic, government took special interest in film as a means of information, education, entertainment the citizenry and documentation aspects of their lives. Worthy of mention in this regard was the efforts of the Western Regional Government in documenting major events in film. The film unit of the Ministry of Information under which culture was subsumed travelled throughout the region documenting important 
events such as festivals, dances and the like. The Federal Film Unit did the same for the entire country. Mention must also be made of some agencies who have in their charge films of performances of Nigerian popular musicians for example the Centre for Black and African Arts and Civilisation (CEBBAC) have films of FESTAC containing the performance of distinguished Nigerian popular musicians who participated in the event. The research should make efforts to avail him/her self of what is available as their utilization will unveil aspects of popular music performance that has not been captured in literature.

\section{Information and Communication Technologies (ICT) Sources}

The tremendous strides registered by technology in the last twenty years have impacted music in recording retrieval, transmission and manipulation. The researcher must be aware of the device that executes these functions and how to deploy them to access data. Prominent among them are the computer and the mobile smart phones and adjunct derives. The possibilities that they open up are unimaginable and require creativity on the part of the researcher to use them properly.

Most importantly is the internet, one of the wonders of the communication era. It enables a scholar to access data from most parts of the word that any research cannot complain of lack of secondary data on virtually any subject. In terms of music research there is a large data base available through YouTube. A researcher can request for music that he needs by using appropriate ICT such as Bluetooth, WhatsApp etc. although ICT is yet to be fully deployed in music research in Nigeria, the enormous possibility is already evident.

\section{Conclusion}

This paper results from a desire to solve the challenge of lack of direction as to sources of some types of data that a researcher may seek in the course of his work. I have stirred to share my personal experiences from the field in order to assist others in a cul-de-sac in this issue of sources and what they portend. We have also used this platform to draw attention to related issues that require attention. 
Research is a continuous endeavour as long as there are humans and society. There will always be challenges as man seek for new sources of data, better ways of improving research tools and analytical techniques - all in one bid to search for truth and sharing our common humanity. This will require the utilization of a withprong approach to data collection and findings.As technology continues to develop new ways of documenting music, the researcher must keep pace with it and be willing and able to deploy such sources in data collection.

*Arugha Aboyowa OGISI, PhD is a lecturer in the Department of Music, Delta State University Abraka.

Email: madamedun@yahoo.com 


\section{References}

Alaja-Browne, A. (1985). Juju music: A study of its social history and style. Ph.D.thesis.Department of Music, University of Pittsburgh.

Awoyinfa, M. (1992).Ebenezer Obey: The Legend's own story. Ibadan:Paperback Publishers Limited.

Emielu, A. M. (2009).Origin, development and sustenance of Highlife Music in Nigeria Unpublished Ph.D. Thesis, Department of the Performing Arts, University of Ilorin.

Idolor, E. G. (2001).Okpe Disco: A study of neo-traditional popular music genre. Unpublished Ph.D. Thesis, Institute of African Studies, University of Ibadan.

Loko, O. O. (2009). The growth and challenges of music recording industry in Nigeria, 1940-2000.Unpublished Ph.D. Thesis, Institute of African Studies, University of Ibadan.

Nzewi, M. (1980). 'Some Reflections on Research.'Ikenga, 4(2), 55 70

Ogisi, A. A. (2009) The Evolution of Popular Music in Southwestern Nigeria.Unpublished Ph.D. Thesis, Institute of African Studies, University of Ibadan.

Oikelome, A. (2009). Stylisic Analysis of Afro Beat Music of FelaAnikulapoKuti.Unpublished Ph.D. Thesis, Institute of African Studies, University of Ibadan.

Okereke, N. M. (1988). OsitaOsadebe: the Highlife Legend. Unpublished MA Thesis, Institute of African Studies, University of Ibadan.

Olusoji, S. (2009).Comparative Analysis of Islam Influenced Apala, Sakara and Waka Popular Music of the Yoruba.Unpublished Ph.D. Thesis, Institute of African Studies, University of Ibadan.

Omojola, B.(2006).Popular music in Western Nigeria. Ibadan: IFRA.

Uwaifo, V. (1975).My Life. Accra: Ghana Black Bell Publishers. 
Ogisi: Sourcing Data in Popular Music Research in Nigeria

Appendix I: Music Journals in Nigeria

\begin{tabular}{|c|c|c|c|}
\hline SN & $\begin{array}{l}\text { Name of } \\
\text { Journal }\end{array}$ & Publisher & $\begin{array}{l}\text { Year of } \\
\text { commencement }\end{array}$ \\
\hline 1. & $\begin{array}{l}\text { Awka Journal } \\
\text { of Research in } \\
\text { Music and the } \\
\text { Arts }\end{array}$ & $\begin{array}{l}\text { Department of Music, } \\
\text { NnamdiAzikiwe } \\
\text { University, Awka. }\end{array}$ & 2003 \\
\hline 2. & $\begin{array}{l}\text { Alvan Journal } \\
\text { of Music and } \\
\text { Humanities }\end{array}$ & $\begin{array}{l}\text { Department of Music, } \\
\text { AlvanIkoku College of } \\
\text { Education, Owerri }\end{array}$ & 2009 \\
\hline 3. & $\begin{array}{l}\text { Interlink: A } \\
\text { Journal of } \\
\text { Research in } \\
\text { Music }\end{array}$ & $\begin{array}{l}\text { Society for interlink in } \\
\text { music research (SIMR), } \\
\text { Department of Music, } \\
\text { NnamdiAzikiwe } \\
\text { UniversityAwka. }\end{array}$ & 2002 \\
\hline 4. & $\begin{array}{l}\text { Journal of the } \\
\text { Association of } \\
\text { Nigerian } \\
\text { Musicologists }\end{array}$ & $\begin{array}{l}\text { Association of Nigerian } \\
\text { Musicologists. }\end{array}$ & 2005 \\
\hline 5. & $\begin{array}{l}\text { Nigerian Music } \\
\text { Journal }\end{array}$ & $\begin{array}{lr}\text { Nigerian } & \text { Music } \\
\text { Initiative, Department } \\
\text { of Music, Delta State } \\
\text { University, Abraka }\end{array}$ & 2012 \\
\hline 6. & $\begin{array}{l}\text { Nigerian Music } \\
\text { Review }\end{array}$ & $\begin{array}{l}\text { Department of music, } \\
\text { ObafemiAwolowo } \\
\text { University, Ile-Ife }\end{array}$ & 1977 \\
\hline 7. & $\begin{array}{l}\text { Nsukka Journal } \\
\text { of Music Arts } \\
\text { Research } \\
\end{array}$ & $\begin{array}{l}\text { Department of Music, } \\
\text { University of Nigeria, } \\
\text { Nsukka }\end{array}$ & 2012 \\
\hline 8. & $\begin{array}{l}\text { Obodom: Journal } \\
\text { of Music and } \\
\text { Aesthetics } \\
\text { (JOMA) }\end{array}$ & $\begin{array}{l}\text { Department of Music, } \\
\text { University of Uyo }\end{array}$ & 2011 \\
\hline 9. & $\begin{array}{l}\text { UneAbraka } \\
\text { Music Journal }\end{array}$ & $\begin{array}{l}\text { Department of Music, } \\
\text { Delta State University, } \\
\text { Abraka }\end{array}$ & 1995 \\
\hline
\end{tabular}

Source: Compiled by Author 
Appendix II: List of Major Journals Dedicated to Popular Music and Related Studies Worldwide

\begin{tabular}{|l|l|}
\hline SN & Name of Journal \\
\hline 1. & Popular Music (Cambridge University Press) \\
\hline 2. & Song and Popular Music \\
\hline 3. & Journal of popular music Studies \\
\hline 4. & Popular Music (Adrain Press) \\
\hline 5. & Popular Music and Society \\
\hline 6. & Popular Music History \\
\hline 7. & Popular Musicology online \\
\hline 8. & $\begin{array}{l}\text { Perfect beat: Pacific Journal of Research into contemporary } \\
\text { Music and Popular Culture }\end{array}$ \\
\hline 9. & Lied and Popular Culture (Song) \\
\hline 10. & Journal of the Arts of Record Production \\
\hline 11. & Journal of Popular Culture \\
\hline 12. & Journal of World Popular Music \\
\hline 13. & Escher's Journal of New and Popular Music \\
\hline 14. & Echo: A music centred Journal \\
\hline 15. & $\begin{array}{l}\text { Chapter and Verse: A Journal of Popular Music and literature } \\
\text { studies }\end{array}$ \\
\hline 16. & Volume: The French Journal of Popular Music Studies. \\
\hline
\end{tabular}

Source: Compiled by Author

\section{Notes}

${ }^{1}$ Stations with such vintage recordings include the FRCN in Lagos, Ibadan, Enugu, and Kaduna also the NTA in Lagos, Ibadan, Benin City, Enugu, and Kaduna. Some government parastatals such as the CEBBAC and the film section of the arts council of some of the state governments also keep some form of film archive.

${ }^{2}$ They are unable to pay for their services of the artist as was the case before 1985 . 